\title{
Governance kulturou tažené urbánní regenerace: Př́padová studie Černá louka v Ostravě
}

\section{Culture-led Urban Regeneration Strategy from the Governance Perspective: A Case Study of Černá louka in Ostrava}

\author{
Blanka Marková, Ondřej Slach
}

\begin{abstract}
The aim of this article is to evaluate a project of planned cultural cluster called Černá louka ("Black Meadow") in Ostrava. The concepts of urban governance, political cycles and culture-led regeneration are used for the purposes of the evaluation. Establishing this cultural cluster was the "flagship" project of the unsuccessful candidacy of the city of Ostrava for the title of European Capital of Culture 2015. The project's scope and focus undoubtedly created the biggest challenge for the city in its modern history. The nature of the project indicates the societal relevance of this article. Even though the project was not successful, it provides a number of implications for understanding not only the future development of the city of Ostrava, but also other towns with a similar history in the post-socialist context.
\end{abstract}

KEY WORDS Culture, urban regeneration, governance, European Capital of Culture, Ostrava

\section{Úvod}

Zvyšující se intenzita ekonomické globalizace, hnaná procesy internacionalizace, liberalizace či evropské integrace, zrcadlící se v narůstající konkurenci na všech hierarchických úrovních, má za následek prohlubující se polarizaci mezi „úspěšnými“ a „neúspěšnými“ městy. Významný faktor diferenciace mezi „úspěšností “ a „neúspěšností“ měst představuje jejich schopnost přitáhnout mobilní kapitál (investiční, lidský), přičemž tato schopnost se odvíjí stále více od schopnosti měst generovat vysokou symbolickou hodnotu, respektive projekty tuto hodnotu utvářející. Není proto nijak překvapivé, že významnou skupinu mezi „neúspěšnými“ městy reprezentují stará průmyslová města (Lash a Urry 1994), která přibližně od 70. let minulého století začala vykazovat problémy s adaptabilitou na postfordistický režim regulace a akumulace (Rumpel a kol. 2008). Manifestací procesu masivní deindustrializace hlavních průmyslových odvětví (uhlí, ocel, chemie, textil) a celkového sociálně-kulturního úpadku se stala narůstající negativní image (Hubbard 1996), která omezovala schopnost atrakce externího mobilního kapitálu, nezbytného pro regeneraci měst (Spaans 2004). I proto se řada průmyslových měst ve vyspělých ekonomikách snažila za účelem zlepšení image o ,agresivní redefinici svých identit a image“ (Miles a kol. 2000: 5), která měla zlepšit jejich schopnost přitáhnout externí mobilní kapitál. Tyto snahy vysvětlují i rostoucí popularitu

Sociální studia. Katedra sociologie FSS MU, 4/2013. S. 127-143. ISSN 1214-813X. 
eventu Evropské hlavní město kultury $(\mathrm{EHMK})^{1}$ jako politicko-ekonomického nástroje, přičemž na organizaci kulturního ,spektáklu“ nahliží jednotlivá města jako na jedinečnou př́ležitost profilovat se na globálním jevišti. Miles (2007: 126) komentuje roli kultury v tomto procesu jako „klíč, který přepisuje status měst, která kandidují na titul EHMK“. Titul EHMK bývá využíván také jako nástroj pro posílení sociální inkluze, rozvoj kulturního cestovního ruchu, regenerace městských center, revitalizace zastavěných ploch, brownfields i veřejných prostor. Estetizace zastavěných prostor je $\mathrm{v}$ západoevropských zemích součástí nového politického diskurzu, který zdůrazňuje práci s pamětí těchto míst (memory work, Ploger 2001: 68). Práce s pamětí má napomoci obnovit komunitní spolupráci, aktivizovat obyvatele a sítě s cílem posílit samoregulační a samosprávní procesy.

Ostrava jako klasické průmyslové město čelí od roku 1989 podobným výzvám jako její protějšky ve vyspělých ekonomikách. Přestože dopady kulturou tažené regenerace v kontextu EHMK v jiných průmyslových městech nebyly vždy jednoznačné, i Ostrava se v roce 2009 zapojila do soutěže o získání titulu EHMK. Za hlavní vlajkový projekt (Bianchini a kol. 1992) byla zvolena výstavba socio-kulturního klastru Černá louka. Cílem našeho př́spěvku je analýza a hodnocení tohoto projektu v kontextu urbánní governance a kulturou tažené regenerace, přičemž níže rozpracované hodnocení navazuje na již realizované výzkumy v oblasti kulturou tažené regenerace v Ostravě, respektive tyto výzkumy prohlubuje (Slach a Boruta 2012).

Pro potřeby tvorby textu byl využit koncept governance ${ }^{2}$, a to v jeho analytické dimenzi, která zahrnuje a) aktéry a instituce (interakce, moc), b) strukturální rámce, c) normativní orientace (Kooiman 2003), přičemž vzhledem k předmětu studia byl širší koncept governance redukován na urbánní governance a jejich režimy (DiGaetano a Strom 2003). Za účelem přesnější identifikace režimů governance byly využit koncept politických cyklů (Jann a Wegrich 2003; Bernt a kol. 2010), který byl vzhledem k povaze projektu Černé louky redukován na:

- definici problému (okolnosti vedoucí $\mathrm{k}$ vytvoření nové politiky),

- nastavení agendy (seznámení s existencí socioekonomického problému),

- formulaci politiky (možnosti nastavení politiky),

- proces rozhodování (specifikace cílů a nastavení nástrojů, jak cílů dosáhnout).

Titul Evropské hlavní město kultury je udělován od roku 1985 každoročně Evropskou unií za finanční podpory Evropské komise a tento event je již sám o sobě významným brandem (Evans 2003). Za autory kulturního programu, který má napomoci při vytváření společné evropské identity a posílit tak legitimizaci Evropské unie (Mokre a Sassatelli 2002), jsou považováni bývalá řecká ministryně kultury Melina Marcouri a bývalý francouzský ministr kultury Jack Lang. Z původně ročního kulturního festivalu v zavedených kulturních metropolích (jako například Atény, Florencie) se titul EHMK stal součástí rozvojových strategií řady evropských měst a regionů, které vsadily na rozvoj prostřednictvím kultury.

2 „Governance města je množinou struktur a procesů, jejichž prostřednictvím různí aktérii, individuální i institucionální, z veřejného i soukromého sektoru, plánují a řídí řešení problémů společného zájmu. Governance města zahrnuje jak formální instituce, tak i neformální struktury (informal arrangements) a také sociální kapitál občanů. Jedná se o kontinuální procesy, jejichž prostřednictvím jsou řešeny konfliktní a různorodé zájmy těchto aktérů, a tím je umožněna kooperativní akce pro řešení určitých problémů“ (UN-Habitat 2009). 
Získaná data pro koncipování tohoto článku jsou založena na kvalitativních výzkumných metodách (Blaxter a kol. 2001) jako participativní pozorování (autoři článku spolupracovali na kandidatuře Ostravy na titul EHMK), semistrukturované rozhovory, analýza mediálních výstupů, veřejné prezentace, kompilace literatury. I když byli oba autoři aktéry kandidatury Ostravy na titul EHMK 2015, mají po čtyřech letech uplynulých od realizace od projektu odstup.

\section{Governance urbánní regenerace tažené kulturou}

V kontextu přechodu městských ekonomik zaměřených na výrobu na městské ekonomiky zaměřené na spotřebu začala města akceptovat, že podpořit jejich ekonomickou bázi lze i prostrednictvím atrakce kvalifikované pracovní síly a turistů (Richards 2000). Sama kultura pak může být právě faktorem, který může kvalifikovanou pracovní sílu (kreativní třídu [Florida 2002]), návštěvníky a investory do měst nalákat, přičemž kultura odlišuje jednotlivá města od sebe navzájem, a díky tomu získává zásadní roli (jako katalyzátor či motor rozvoje) v urbánních regeneračních strategiích v post-industriální společnosti (Evans 2005). Při propojování kultury a územního rozvoje dochází, podobně jako u všech dalších aktivit zaměřených na proměnu sociálního, fyzického či funkčního prostředí, k vytvoření nových politických vztahů, koalic a konfliktů (Grodach a Silver 2013). Jiná stanoviska a zájmy zastupují jednotliví aktéři regenerace tažené kulturou, at’ už je to veřejná správa, zvolení politici, developeři, místní obyvatelé, kulturní organizace a neziskový sektor, přičemž jednotliví aktéři mají jak rozdílné možnosti prosazení svých zájmů, tak disponují i rozdílnými zdroji a kapacitami (at' už personálními, vědomostními, organizačními či finančními). Vysoká komplexita tak vyžaduje od měst vysoké časové a koordinační náklady za účelem nalezení společenského konsensu (vize) pro potřeby kulturou tažené regenerace, což tento přístup problematizuje.

Termín urbánni regenerace zahrnuje dle Langa (2005: 7) integrovaný př́ístup měst k řešení jejich úpadku a transformace. Naplnění tohoto cíle, tj. prosazení pozitivní změny (obnovení růstu ekonomických aktivit, zlepšení kvality životního prostředí a posílení sociální inkluze), je dosahováno prostřednictvím strategií, nástrojů a projektů v sociální, environmentální, kulturní a ekonomické oblasti (Couch a Cocks 2011).

Role kultury je v tomto př́ípadě spatřována v možnosti zlepšit kvalitu urbánního života; kultura může přispět zejména $\mathrm{k}$ formování silnější sousedské identity a posílení participace na veřejném životě (Ploger 2001: 68). Kultuře bývá také připisována funkce vytváření kolektivních identit, zvyků a hodnot (De Frantz 2013). Ta samá autorka však na druhou stranu upozorňuje, že kultura může být zneužita politickými představiteli k mobilizaci volebních hlasů, například pokud je investováno do významných a viditelných projektů, které mají za cíl zastínit závažnější sociální či ekonomické problémy (De Frantz 2013). Kultura bývá $\mathrm{v}$ některých př́ípadech instrumentalizována, stává se nástrojem $\mathrm{k}$ získání moci i finančních prostředků. I přes tyto kritické ohlasy na možné zneužití kultury nelze význam kultury naprosto zavrhnout, protože to může být právě kultura, která může napomoci zlepšení image průmyslových měst a na jejímž základě může docházet ke vzniku sociálních a kulturních inovací (Kunzmann 2002; García 2004).

Je třeba zdůraznit, že pokud hovoříme o kulturou tažené regeneraci měst, jsou tím myšleny aktivity jako kulturní vlajkové projekty, tzn. „design a (re)konstrukce budov 
s různým funkčním využitím, budování kulturní infrastruktury, kultivace veřejného prostoru, kulturní programy a eventy atp., přičemž vlajkovými projekty jsou označovány obvykle ikonické stavby, které vytvárí nové urbánní prostory“ (Short a kol. 1993: 209), které mají plnit roli katalyzátoru urbánní regenerace (Bianchini a kol. 1992). Zmíněné aktivity bývají obsahem evropského eventu EHMK, který řada západoevropských průmyslových měst (Glasgow, Liverpool, Linec, Essen, Marseille a další) využila jako nástroj kulturou tažené regenerace, $\mathrm{s}$ cílem zlepšit svou image a vyprofilovat se $\mathrm{v}$ globálním měřítku mezi ostatními městy. Nicméně podobně jako u jiných typů vlajkových projektů (Swyngedouw a kol. 2002) jsou dopady takovýchto projektů často nejednoznačné. Např́klad tím, že jsou zaměřeny primárně na turisty, mohou vyvolat protesty u lokálních obyvatel, popř́padě mohou prohlubovat (polarizovat) nerovnoměrný rozvoj města a oslabovat sociální kohezi (Little 2008). Uvedené negativní dopady svým způsobem zrcadlí komplexnější neoliberálně orientovaný koncept „podnikatelského města“ (Hall a Hubbard 1996), který akcentuje „,regeneraci taženou řadou spektakulárních projektů, které mají přeměnit image deprivované urbánní oblasti““ (Hall a Hubbard 1996:18).

Pochopitelně nelze plně aplikovat poznání a zkušenosti ze západoevropských měst na předmět hodnocení tohoto textu bez jejich kontextualizace do post-socialistického prostoru, který je i přs proces konvergence stále ovlivněn obdobím centrálně plánované ekonomiky (viz např. Sýkora a Bouzarovski 2012). V prvé řadě, v dosavadní transformaci měst dominoval privátní sektor, přičemž veřejný sektor se soustředil na budování technické a sociální infrastruktury, která byla po období centrálně plánované ekonomiky značně poddimenzována. Slabé postavení veřejného sektoru korespondovalo se slabým rozsahem pravomocí měst, omezenými rozpočty, nedostatkem zkušeností či znalostí na straně jedné (Keivani a kol. 2001). Na straně druhé, pozici privátního sektoru posilovala taktéž preference laissez faire zásady ve vztahu k rozvoji měst (Sýkora 2002). Pokud již vznikají urbánní politiky, pak jsou často instrumentální, krátkodobé či, přesněji vyjádřeno, více než strategickou vizí jsou (pragmaticky) taženy př́ležitostmi v externím prostředí (opportunity-led development, Tasan-Kok 2006). Cílem většiny měst je plně v souladu s jejich neoliberální orientací podpora růstu (Rink a kol. 2012). Navíc znalostní poddimenzovanost bývá často nahrazována transferem příkladů dobré praxe ze zahraničí bez jejich nezbytné kontextualizace (Sagan a Grabkowska 2012).

Výše uvedená stručná kontextualizace naznačuje, že nejen způsob řízení měst, ale také dosavadní malé zkušenosti měst v oblasti velkých urbánních investic, či přesněji vlajkových projektů $\mathrm{v}$ kontextu kulturou tažené regenerace, představují pro města $\mathrm{v}$ post-socialistickém kontextu velkou výzvu. Česká republika bude hostovat event EHMK v roce 2015 společně $\mathrm{s}$ belgickým městem Mons, kdy jedním z nominovaných měst bylo i město Ostrava. Město sice ve své snaze získat tento titul neuspělo, nicméně svoji kandidaturu postavilo na vlajkovém projektu regenerace bývalého brownfieldu Černé louky na socio-kulturní klastr, což nám umožňuje, byt' jen dílčím způsobem, analyzovat a hodnotit tento projekt. Tomu bude věnována následující část textu. 


\section{Historie a popis zájmového území Černá louka}

Černé louka se nachází v centru města Ostrava, v blízkosti historického Masarykova náměstí. Město Ostrava (301942 obyvatel v roce 2011) je administrativním centrem Moravskoslezského kraje a nachází se v severovýchodní části České republiky. Struktura města byla značně ovlivněna procesem industrializace a spontánní urbanizace, která byla započata v polovině 19. století. Město je charakteristické chaotickou výstavbou, promícháváním funkcí a multi-jádrovou rezidenční strukturou (Rumpel a kol. 2012b). Černá louka ve své historii nese odkazy na jednotlivá období vývoje Ostravy.

Černá louka byla až do roku cca 1870 podvyužívanou lokalitou v centru Ostravy. Ke konci 19. století se sem začaly vyvážet výpěrky z koksoven Centrálka a Karolina. Původně se halda navážela pomocí úzkokolejné dráhy, v roce 1911 však již byla tak vysoká, že musela být používána lanovka. Roku 1917 měla halda s několika vrcholy 25 metrů na výšku, zabírala plochu skoro 5 hektarů a uloženo zde bylo více než $700000 \mathrm{~m}^{3}$ hlušiny (Polášek a Žárský 2007). Problém „ostravských Karpat“, jak si haldy překřtili obyvatelé města, se začal řešit po vzniku Československa v roce 1918. Vítkovické horní a hutní těžířstvo zakoupilo rybníky v Hrušově a začalo je obsahem haldy zasypávat. Jak se však záhy ukázalo, rybníky pojaly jen $15 \%$ obsahu haldy. Na haldách žili lidé bez domova (brenpartyje), kteří hledali zbytky uhlí. Ve 20. letech 20. století zde byl na popud místního podnikatele vybudován zábavní park Tivoli s horskou dráhou (délka 420 metrů) po vzoru podobných odpočinkových center v evropských velkoměstech.

Historie výstav a veletrhů v Ostravě se datuje od 17. června 1362, kdy král Karel IV. vydal ostravským měšt’anům privilegium na pořádání šestnáctidenního výročního trhu. Trhy byly již $\mathrm{v}$ té době tematicky zaměřeny, jednalo se o trhy dobytčí a specializované na len a př́zi. $V$ př́pravě trhů tehdy kromě vedení města hrály významnou roli i cechy a sdružení řemesIníků. Nejvýznamnější pozici mezi cechy v Ostravě v 19. století zaujímali řezníci. Ročně tímto trhem prošlo v průměru 60000 prasat, roku 1835 dokonce 80000 kusů. Pro vepře vyrostly ohrady i chlévy v prostoru Černé louky, která tak přišla ke svému názvu: veprrům se $\mathrm{v}$ té době ríkalo „černý dobytek“, proto se část Moravské Ostravy u řeky Ostravice jmenuje Černá louka (Polášek a Žárský 2007).

První výstavou po vzniku Československé republiky byla v Ostravě v roce 1923 „I. Průmyslová a živnostenská výstava v Moravské Ostravě“; ta se ještě nekonala na výstavišti Černá louka, ale v prostorách a halách Vítkovických železáren. Další snahy o organizování výstav byly násilně přerušeny druhou světovou válkou. Od 10. do 24. ř́jina 1954 se konal „První ostravský veletrh“, který navštívilo 220 tisíc návštěvníků. Město Ostrava však stále nedisponovalo odpovídajícím výstavním prostorem a bylo rozhodnuto o výstavbě nového výstaviště na území Černé louky u řeky Ostravice. V roce 1958 byl 13. záắí slavnostně otevřen pavilon A v nově vzniklém výstavním areálu, který nesl název „Park kultury a oddechu“.

Výhodná poloha Černé louky u řeky a požadavek na vytvoření výstaviště ze strany města byly primárními důvody, proč byla $\mathrm{v}$ období komunismu tato plocha rekultivována pro vytvoření výstaviště pro celou ostravskou aglomeraci (Havrlant 1980). Relativně rozsáhlý areál však byl zastavěn jen z části a stále zde existují plochy rekultivované zeleně.

Od roku 1987 areál Černé louky chátral. Po sametové revoluci v roce 1989 se mohlo začít svobodně podnikat a $v$ Ostravě vznikla řada soukromých podnikatelských subjektů 
zabývajících se výstavnictvím. Roku 1990 město Ostrava založilo Ostravskou obchodní společnost a.s., která se starala o provoz výstaviště. V roce 1994 došlo pouze k formálnímu přejmenování městské Ostravské obchodní společnosti a.s. na Černá louka a.s. Areál sloužil jak výstavním, tak obchodním a restauračním účelům. Vedení Černé louky a.s. však nebylo schopno výstaviště patřičným způsobem rozvíjet a v roce 1998 byla společnost zlikvidována se ztrátou 50 milionů korun. Namísto Černé louky a.s. založilo město Ostrava novou společnost Ostravské výstavy a.s., do níž se včlenila i firma místního podnikatele Karla Burdy Výstavy Ostrava, přičemž pan Burda se stal ředitelem nově vznikající společnosti. Město do nové společnosti vložilo jeden milion korun základního jmění a zastupitelé města Ostravy jsou členy dozorčí rady akciové společnosti. Potřebných 73 miliónů do oprav chátrajícího areálu musela společnost uhradit $\mathrm{z}$ vlastních zdrojů. V pětihektarovém areálu je umístěno devět objektů, z toho dva výstavní a kongresové pavilony. Pozemky i většina budov je ve vlastnictví statutárního města Ostrava, což „představuje pozitivum pro budoucí rozvoj města“ (rozhovor Hrotík 2010). Venkovní plochy a travnatá zóna poskytují návštěvníkům i obyvatelům centra města místo pro odpočinek. Dominantou je pavilon A, který je tvořen původní historickou budovou z roku 1960 a zánovní víceúčelovou halou s podzemními parkovacími prostory, přičemž disponuje hrubou výstavní plochou $6300 \mathrm{~m}^{2}$. Ročně se na výstavišti koná téměř 100 výstav, konferencí, seminářů a jiných kulturně-společenských akcí. V dalších budovách výstaviště stabilně sídlí některé obchody, hudební kluby, kavárna, golfový simulátor, sklep strašidel či mořské akvárium. Bludné balvany nacházející se $\mathrm{v}$ areálu jsou dokladem pevninského zalednění skandinávského původu na ostravském území ve čtvrtohorách. Jedná se o chráněný prrírodní výtvor plnící dekorativní funkci ve veřejném prostoru.

Město ze začátku dotovalo Ostravské výstavy a.s. roční částkou 20 milionů korun, dnes tato suma činí 11 milionů korun a lze očekávat další snižování př́spěvku (rozhovor Burda 2013). Ostravské výstavy a.s. provozují i přilehlý areál Slezskoostravského hradu a svět miniatur Miniuni. Vedle organizování výstav a společenských akcí probíhal do roku 2011 v areálu i nadregionálně významný festival world music Colours of Ostrava, který má průměrnou návštěvnost 25000 návštěvníků během čtyř dnů trvání festivalu. Důležitým milníkem ve vývoji areálu Černé louky se stala kandidatura města Ostravy na titul Evropské hlavní město kultury 2015.

\section{Definice problému a nastavení agendy}

I přses výše jmenované aktivity prostor Černé louky chátral a město hledalo jeho nové využití, přispívající k oživení upadajícího centra města, které vykazuje dlouhodobý demografický pokles (Rumpel a Slach 2012b). Nezastavěné plochy na Černé louce poukazovaly na slabý trh s nemovitostmi v centru města. Magistrát města Ostravy (MMO) měl dokonce v úmyslu Černou louku v roce 2007 prodat developerům a nebýt krize v roce 2008, možná by se tak i stalo. Př́chod ekonomické krize měl na město dvojí dopad. V první řadě krize zapř́ŕcinila pokles poptávky developerů z dynamického období po roce 2004 . V druhé řadě krize narušila dosavadní strategii externě orientovaného ekonomického rozvoje založeného primárně na atrakci prímých zahraničních investic prostřednictvím nízkých cen vstupů (tzv. low-road strategie), což přimělo město ke změně orientace směrem k podpoře endogenního ekonomického rozvoje založeného 
na inovacích, kvalitě života a kvalitním institucionálním prostředí (tzv. high-road strategie). Do této nové strategie plně zapadala kandidatura města na titul EHMK. Mimo dopad na celé město nabízel zisk titulu př́ležitost oživit upadající centrum města a přilehlé oblasti.

Slabé stránky města (brownfield v centru města, proluky z druhé světové války, chátrající budovy $\mathrm{z}$ osmdesátých let $\mathrm{v}$ duchu tehdejší ideologie) jsou projektem citlivě uchopeny a obráceny $\mathrm{v}$ přednost. Stěží najdeme jiné evropské město umožňující vytvořit takto rozsáhlý urbanisticko-architektonický projekt postavený na principech 21. století. (OSTRAVA 2015 2010: 52)

Impuls ke kandidatuře statutárního města Ostravy na titul EHMK 2015 vzešel z Národního divadla Moravskoslezského, avšak napoprvé se tato myšlenka nesetkala s kladnou odezvou vedení města. Významným argumentem pro př́ípravu kandidatury byla až návštěva zástupců města Ostravy v průmyslovém městě Essen (Německo), na jejímž základě Komise kultury rady města Ostravy přijala myšlenku kandidatury za svou. Město Essen leží ve starém průmyslovém regionu Porúř́i, který vsadil od počátku 90. let na regeneraci taženou kulturou (Rumpel a kol. 2008). Díky iniciativě členů komise a podpoře vedoucí pracovnice Odboru kultury, sportu a volnočasových aktivit Magistrátu města Ostravy započala v roce 2007 př́prava kandidatury. Vedení města si uvědomilo rozsah a náročnost projektu a vyzvalo $\mathrm{k}$ řizení projektu odborníky z oblasti kultury. Pro př́pravu předvýběrového kola a sepsání přihlášky do soutěže získala společnost První veřejnoprávní s.r.o., patřící řediteli projektu Čestmírovi Kopeckému, účelovou dotaci od Statutárního města Ostravy (SMO). Za účelem splnění požadavků Evropské komise na kandidátská města (navázání projektu na kulturní politiku města) nechalo statutární město Ostrava zpracovat Analýzu kultury v Ostravě (Univerzita Karlova 2008), na jejímž základě byla vypracována Koncepce rozvoje kultury statutárního města Ostravy do roku 2020 (první strategický dokument, který se věnuje kulturní politice města). Cíle projektu Ostrava 2015 vycházely právě z ad hoc vznikající Koncepce rozvoje kultury a ze Strategického plánu rozvoje statutárního města Ostravy 2009-2015. Primátor Ostravy koncem března 2009 oficiálně ohlásil kandidaturu města na titul Evropské hlavní město kultury.

\section{Formulace politiky}

Na základě postupu do druhého kola kandidatury založilo statutární město Ostrava nezávislou společnost Černá louka s.r.o. (název odvozen od vlajkového projektu regenerace bývalého brownfieldu), která měla za úkol připravit druhou rozšířenou verzi přihlášky reagující na otázky komisařu z prvního výběrového kola, realizovat návštěvu komisařu ve městě a zintenzivnit vztahy mezi participujícími institucemi a aktéry. Financování kandidatury bylo opět celé kryto ze zdrojů statutárního města Ostravy ve formě účelové dotace, čímž Černá louka s.r.o. naplňovala charakteristiky úspěšných intermediárních institucí. Tyto instituce jsou částečně autonomní a disponují jistou exkluzivitou, která je dána dispozicí s jistým finančním obnosem a silnou politickou podporou (Slach a kol. 2009).

Na základě konsenzu mezi jednotlivými aktéry projektu bylo na EHMK pohlíženo jako na možnost funkčního a symbolického dokončení procesu restrukturalizace regionu a přechodu z industriální na postindustriální společnost. Pilotním projektem ostravské 
kandidatury byl návrh regenerace území Černá louka se záměrem vytvoření socio-kulturního klastru.

Kulturní klastr může vytvořit zásadní identifikační element pro místní obyvatele a posílit regionální identitu. Vedle faktické hodnoty navyšuje i symbolickou hodnotu místa: stává se jednou $\mathrm{z}$ dominant mediálního obrazu a obecné představy o městě. Dobré klastry patří $\mathrm{k}$ tomu prvnímu, nač si v souvislosti s jejich městem vzpomeneme. (OSTRAVA 2015 2009: 51)

\section{Př́padně:}

Klastr představuje, v př́padě realizace, kličový prvek tvorby nové „postindustriálni““ image Ostravy (OSTRAVA 2015 2010: 75).

Idea kulturního klastru byla, zejména $\mathrm{v}$ počátečních úvahách, inspirována podobnými projekty v Bostonu, Bilbau, Essenu, Manchesteru a v dalších průmyslových městech.

Analýza současných evropských měst ukazuje, že se o podobnou koncentraci kapitálu snaží, at' už se jedná o urban renewal (regeneration) (Glasgow, Manchester, Liverpool, Bilbao, Almere,

Obrázek 1: Vítězný návrh Černé louky z dílny architektonického studia MAXWAN

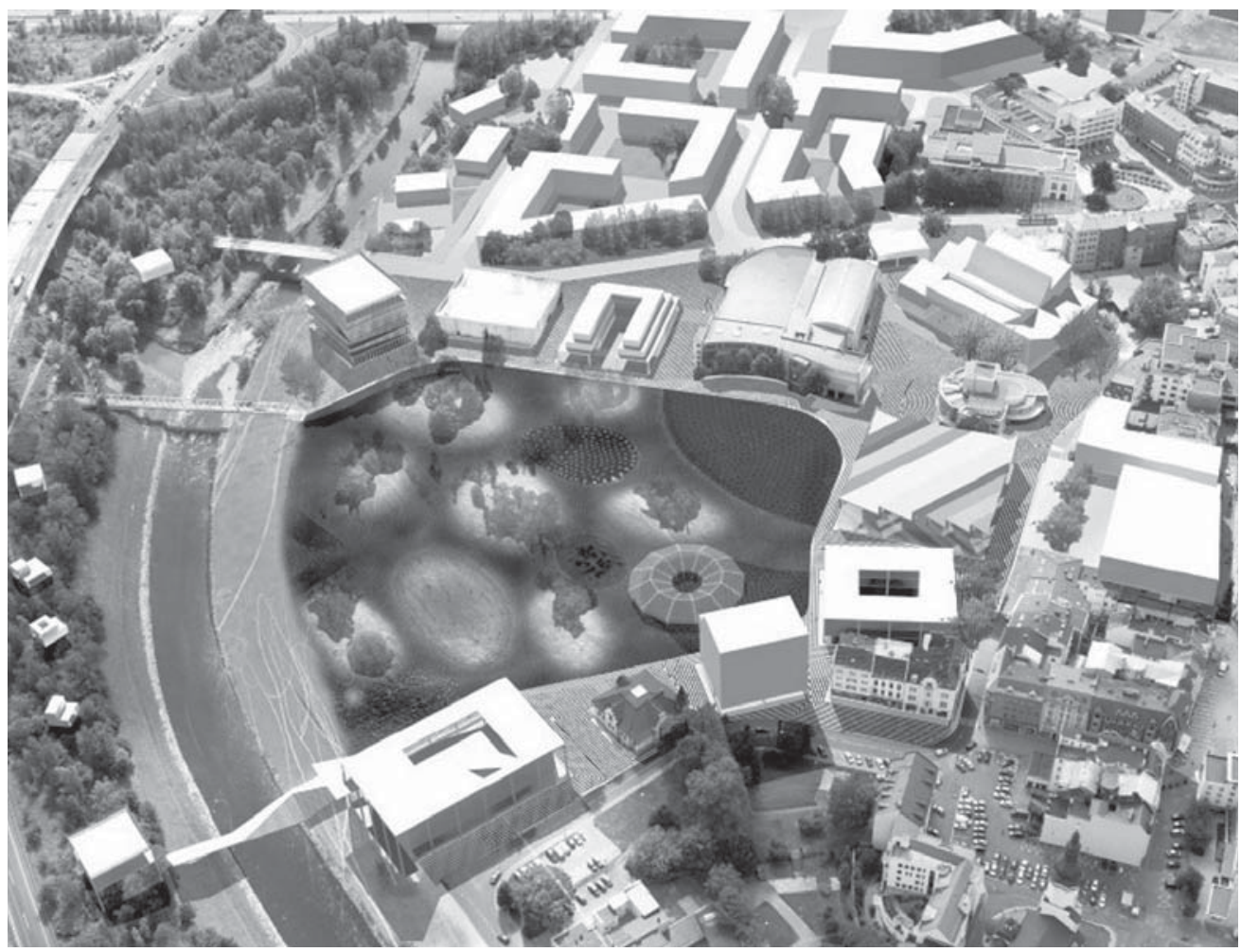

Zdroj: Maxwan 
Lille, Canary Wharf v Londýně), nebo koncentraci kulturních staveb na jedno místo (Vídeň, Linz, Leon, Barcelona - Forum 2004, Valencia nebo Rotterdam). (OSTRAVA 2015 2009: 72)

\section{Př́ípadně:}

Jako př́klad si uved’me bostonský klastr, jehož hlavní náplní je life-science. Na relativně malém území najdeme jednu z nejprestižnějších světových škol MIT (Massachusetts Institute of Technology), která každý rok vyprodukuje stovky doktorandů s titulem PhD., sestavu research hospitals (výzkumných nemocnic), kde mohou tito studenti své výzkumy provádět, a jen o malý kousek vedle „obyčejné“ nemocnice, které poznatky nashromážděné v předchozích dvou místech okamžitě využívají. Výsledkem je nejen kvalitní zdravotní péče a 60000 zaměstnanců v tomto oboru, ale především suverénně nejvyšší množství úspěšných patentů (3 800 v letech 1996-2000). Lifescience klastr však netvoří pouze tyto tři instituce, aby mohl úspěšně fungovat, musíme k němu započíst další kritéria. Snadnou dopravní dostupnost (jak v makro - mezinárodní letiště, tak v mikro měřítku - nedaleká vzdálenost od dopravně dobře obslouženého centra), kvalitní bydlení, zeleň a rekreační plochy v návaznosti na řeku. Při podrobnějších studiích zjistíme, že toto, spolu s mimořádně důležitou pěši přístupností, představuje nezbytná kritéria pro vytvoření klastru. (OSTRAVA 2015 2009: 71)

Současně reflektovala, alespoň dílčím způsobem, reálné potřeby obyvatel města či samotné umělecké scény. $\mathrm{V}$ rámci klastru alias „nové výstavní čtvrti“ měla vzniknout nová budova filharmonie a městské galerie (Kunsthalle), vysoká škola kulturního managementu včetně inkubátoru pro kreativní odvětví, mateřská, základní a střední umělecky zaměřená škola a budova prístavby stávajícího Divadla loutek. Vedle výstavby těchto budov se předpokládala kultivace veřejné zeleně, revitalizace řeky Ostravice a regenerace nábřeží a rozvoj dalších funkcí (bydlení, služby).

Silná inspirace př́iklady „dobré praxe“ z jiných měst byla kritizována komisí v zprávě z 1. kola řízení (předvýběrová fáze), kde bylo uvedeno:

Byly vyjádřeny určité pochybnosti kolem plánu „Černá louka“, který tvoří jednu z hlavních položek na seznamu projektů. Plán je velmi ctižádostivý a vyžaduje značné finanční prostředky. Pokud jde o srovnání projektu „Černá louka“ s jinými evropskými projekty (areály), členové výběrové komise vyjádřili pochybnosti o možnosti/vhodnosti zevšeobecňování prezentovaných závěrů, protože je dobře známo, že ne všechny podobné developerské snahy se setkaly s úspěchem. (Zpráva komise 2009: 5)

Na základě této připomínky byla prohloubena lokální dimenze kulturního klastru, a to jak ve vztahu k potenciálu města jako celku, tak především v zasazení kulturního klastru $\mathrm{k}$ dalším prostorově blízkým územím: městského jádra, městského parku, Dolní oblasti Vítkovic, Nové Karolině a ke Stodolní ulici (Ebert a Gnad 2010, viz obrázek 2).

Za účelem př́ípravy urbanistické soutěže na revitalizaci území byla sestavena pracovní skupina složená ze zástupců Útvaru hlavního architekta Magistrátu města Ostravy, Odboru ekonomického rozvoje MMO, Společnosti Petra Parléře (organizátor soutěže) a nezávislých architektů. Mezinárodní veřejná kombinovaná urbanistická soutěž byla financována ze zdrojů odboru hlavního architekta města Ostravy a byla vyhlášena 1. února 2010. Zadáním soutěže bylo zpracování návrhu prostorové a funkční koncepce Černé louky. Do uzávěrky soutěže se sešlo na 70 návrhů na budoucí podobu území Černé louky. Jedenáctičlenná porota 
Obrázek 2: Schéma funkční komplementarity Černé louky s dalšími prostory ve vnitřním městě

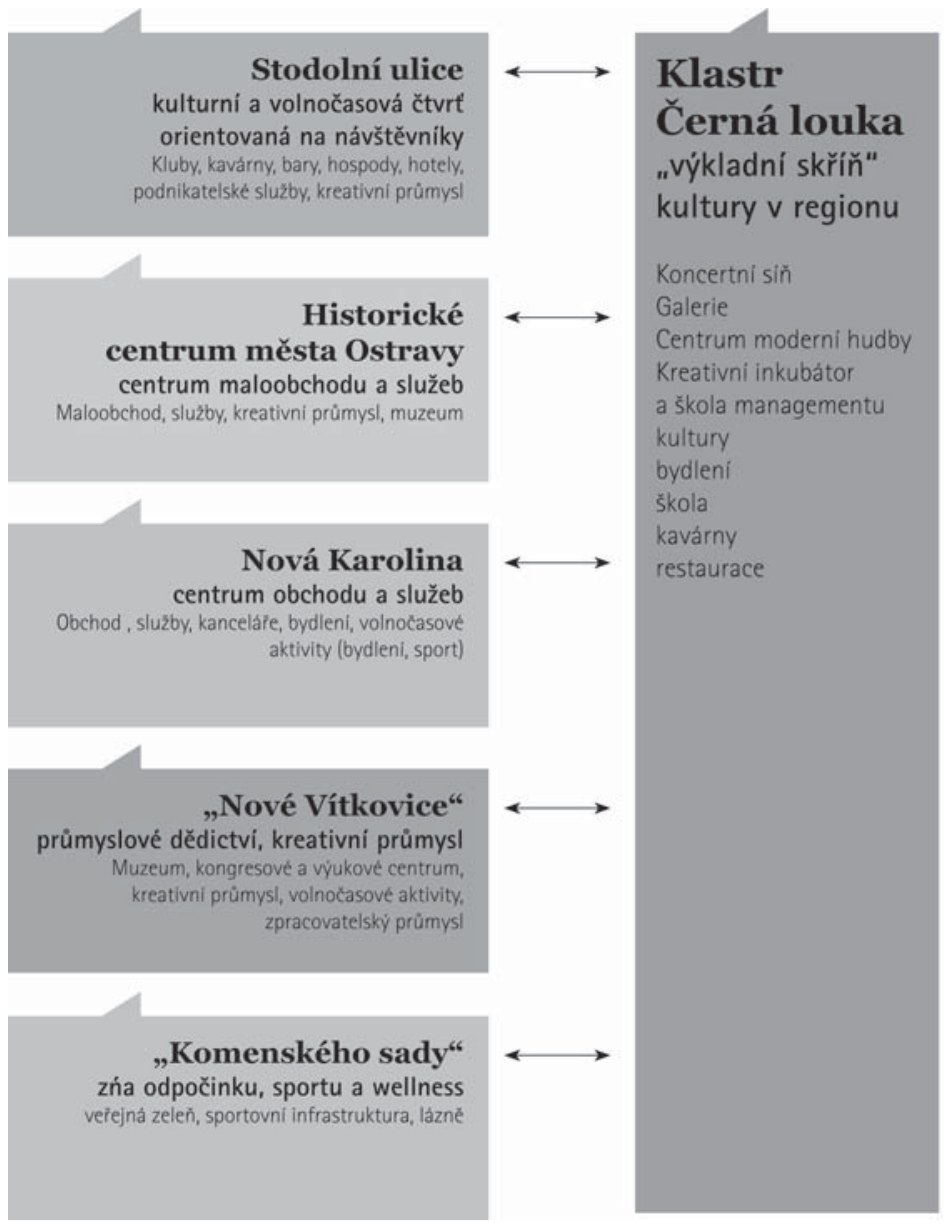

Zdroj: Volně inspirováno dle Ebert a Gnad (2010), neoficiální zdroje přihlášky

složená z renomovaných urbanistů, architektů a zástupců města Ostravy v čele s architektem Josefem Pleskotem dne 18. června vybrala vítěze, kterým se stal návrh nizozemského ateliéru Maxwan. Vítězný návrh zahrnoval oproti původním plánům např́klad i výstavbu hotelu. Plánovaný rozpočet projektu byl odhadnut na přibližně 3,3 miliardy korun. Zastupitelstvo města schválilo pro účely kandidatury částku 2 miliardy korun a značná část měla být směřována na výstavbu kulturního klastru. (Rozpočet města Ostravy v roce 2010 byl 6,4 miliard korun. Hlavním investorem mělo být město a další zdroje pro financování měly pocházet z externích zdrojů, zejména však ze strukturálních fondů [sektorové, regionální operační programy] nebo z finančního nástroje Jessica.) Architekt Lukáš Brus (rozhovor realizovaný v roce 2012), který v pozici soutěžícího participoval v urbanistické soutěži, považuje 
regeneraci taženou kulturou za vhodnou strategii pro další rozvoj města a věří, že regenerace brownfields může přitáhnout nové investory.

V záŕí roku 2010 však určila výběrová komise za vítěze soutěže na titul EHMK konkurenční město Plzeň, což se rozhodujícím způsobem promítlo do další budoucnosti projektu socio-kulturního klastru. Neúspěch kandidatury města zastavil aktivity intermediární agentury Černá louka s.r.o. a de facto přerušil i plány na regeneraci areálu Černá louka.

Obrázek 3: Provázanost historického centra města Ostravy s Černou loukou a Dolní oblastí Vítkovic

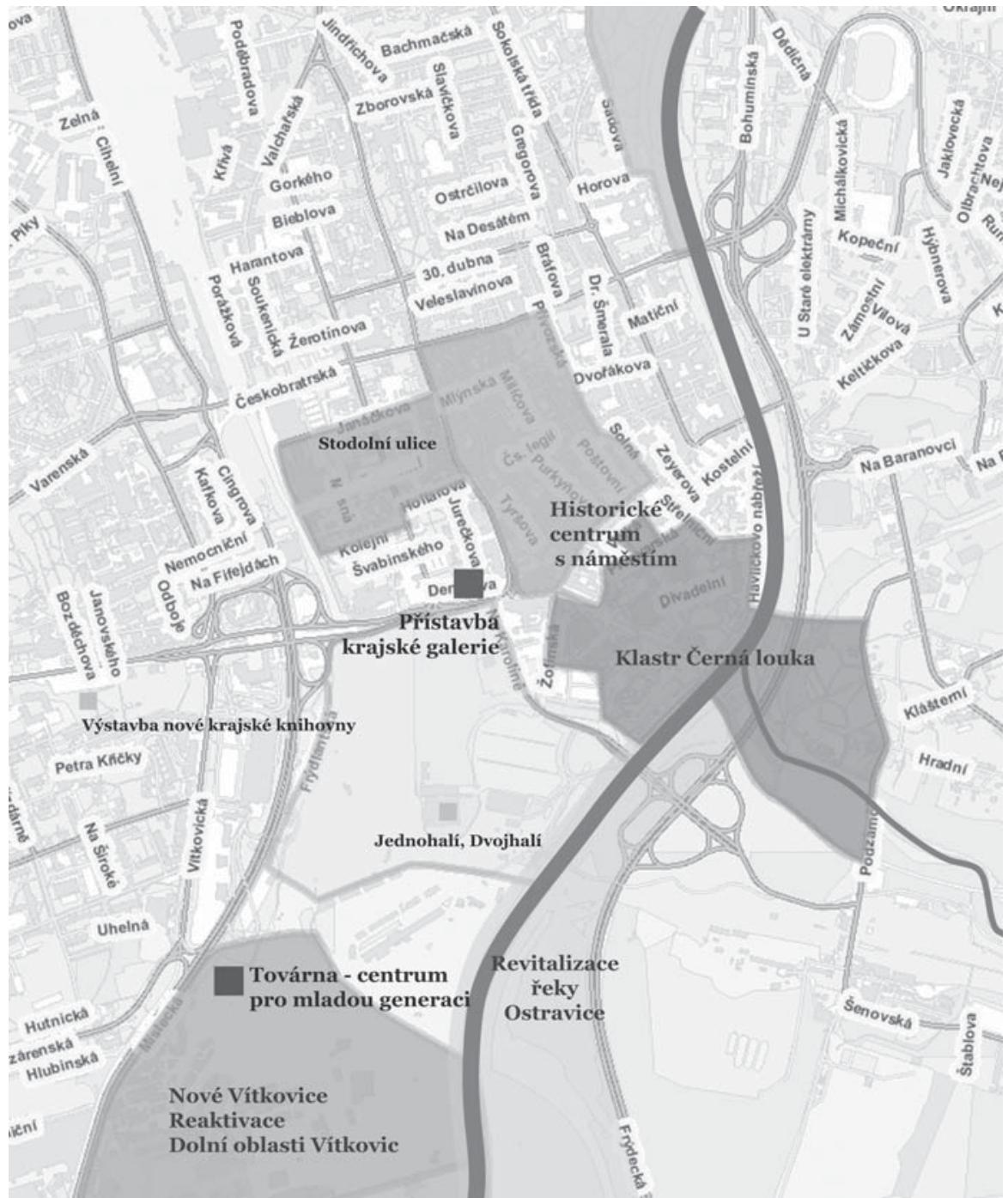

Zdroj: Volně inspirováno dle Ebert a Gnad (2010), neoficiální zdroje přihlášky 


\section{Evaluace kulturou tažené regenerace z perspektivy governance}

Oficiálním cílem kandidatury Ostravy bylo prostřednictvím eventu EHMK zlepšit externí negativní image znečištěného průmyslového města a současně zvýšit kvalitu života prostřednictvím doplnění chybějící kulturní infrastruktury ve městě. Je pravděpodobné, že nebýt možnosti kandidovat na titul EHMK 2015, debata o roli kultury v územním rozvoji města Ostravy by vůbec nenastala, nebo by byla o mnoho let opožděna. Regenerace Černé louky měla navenek reprezentovat politický a ekonomický potenciál města a mobilizovat sociální a politickou podporu interně. Při vytváření ideové stránky projektu regenerace, tedy vytvoření socio-kulturního klastru, se explicitně nepracovalo s pamětí místa, jak navrhuje Ploger (2001), přičemž na tyto aktivity vzhledem ke způsobu plánování a realizace projektu nezbývala časová, personální ani praxí podložená zkušenost (znalostní kapacita). Inspirace pro vytvoření klastru byla přenesena ze zahraničí na základě benchmarkingu s jinými průmyslovými městy v USA a západní Evropě. V kontextu politických cyklů definice problému a nastavení agendy se tak jednalo hlavně o z vnějšího prostředí iniciovaný model (outside initiation model) (Jann a Wegrich 2003), protože idea byla založena nejen na prríkladech z jiných měst, ale byla také iniciována externími aktéry. Až při modifikaci (po prvním výběrovém kole) formulace politiky byl zohledněn lokální kontext, tj. snaha dobudovat chybějící kulturní infrastrukturu ve městě a propojit ji funkčně s dalšími prostory vnitřního města. Role klastru byla zaměřena převážně v nabídce kulturních a vzdělávacích aktivit pro lokální obyvatele, přičemž ale lokální obyvatelstvo nebylo nikterak zapojeno do procesu příprav tohoto projektu. Č́stečně lze o konceptu paměti místa (Ploger 2001) hovořit v souvislosti s faktem, že první ostravský brownfield Černá louka byl v minulosti zregenerován na zábavní čtvrt' Tivoli a později „Park kultury a oddechu“ a jako socio-kulturní klastr měl opět sloužit kulturním a zábavním účelům. Nicméně jednalo se spíše o souhru okolností než o výsledek vědomé snahy při aplikaci konceptu paměti místa. Z hlediska hodnocení v kontextu governance lze identifikovat dva režimy governance (viz tabulka), přičemž zejména druhý identifikovaný režim governance (pluralistický) pro svoji otevřenost a různorodost aktérů a normativní orientaci vykazoval rozdílné rysy od urbánní governance celého města (Rumpel a Slach 2012a).

Ostrava kandidovala na titul EHMK před třemi lety a projekt Černé louky se nezačal realizovat ani v minimalistické podobě. Implementace projektu skončila architektonickou soutěží. Částečně za to může současná ekonomická krize, částečně i fakt, že projekt Černé louky ani samotná kandidatury nebyly součástí dlouhodobé rozvojové strategie. MMO v současnosti (duben 2013) deklaruje zájem vystavět budovu filharmonie. V plánovacím období 2014 až 2020 by na ni chtělo získat peníze z Evropské unie. Podle odborných odhadů by stavba měla stát zhruba miliardu korun, přičemž město Ostrava si od newyorské společnosti, která se podílela na budování Opery v Sydney, už nechalo vypracovat technické podklady pro vyhlášení architektonické soutěže (ČTK 2012), aby do Ostravy nalákalo světoznámé ikonické architekty.

Architektonická soutěž na regeneraci Černé louky byla druhou architektonickou soutěží tohoto rozsahu v Ostravě. První urbanistická soutěž na realizaci Nové Karoliny byla zrušena a nahrazena „developerskou soutěží“ (Rumpel a Slach 2012a). Samotní zástupci jednotlivých odborů magistrátu města Ostravy v období kandidatury připustili, že společně řeší kulturu a její efekty pro lokální a regionální rozvoj poprvé právě až díky kandidatuře na titul EHMK. 
Byly to tedy externí rámcové podmínky, příležitost využít kultury (titulu EHMK) jako prostředku pro získání finančních prostředků z různých zdrojů. Město však nebylo schopno př́ležitosti adekvátně využít. Titul EHMK Ostrava nezískala a aktivity intermediární instituce Černá louka s.r.o. přestaly být městem podporovány. I přesto nastartovala kandidatura dílčí grassroots aktivity, přičemž nejúspěšnější z nich vyústila $\mathrm{v}$ založení multižánrového klubu Cooltour, který sídlí v jedné z budov na Černé louce. Během dvou let dokázali lídři Cooltouru vybudovat kulturní platformu pro podporu tvorby nezávislého umění, jejíž fyzické umístění je však pouze dočasné vzhledem $\mathrm{k}$,plánované“ regeneraci Černé louky, přičemž projekt regenerace je uložen na MMO „V šuplíku“ a město vzhledem k nedostatku finančních zdrojů spíše neví, jak s Černou loukou dále naložit. Nejasnosti ohledně budoucího využití areálu Černá louka přidává také rozvoj průmyslového areálu Dolní oblast Vítkovice, kde byla např́klad otevřena nová městská galerie.

Tabulka 1: Režimy governance ve vazbě na politické cykly

\begin{tabular}{|c|c|c|}
\hline Politický cyklus & $\begin{array}{l}\text { Definice problému } \\
\text { a nastavení agendy }\end{array}$ & $\begin{array}{l}\text { Formulace politiky } \\
\text { a rozhodování }\end{array}$ \\
\hline Výzva, problém & $\begin{array}{l}\text { Regenerace brownfields, doplnění } \\
\text { chybějící kulturní infrastruktury }\end{array}$ & $\begin{array}{l}\text { Image města, kvalita života, podpora } \\
\text { kreativních odvětví }\end{array}$ \\
\hline $\begin{array}{l}\text { Vztahy, koalice, } \\
\text { sítě }\end{array}$ & $\begin{array}{l}\text { Exkluzivní vyjednávání mezi lokální } \\
\text { autoritou a zástupci kulturních institucí }\end{array}$ & $\begin{array}{l}\text { Inkluzivní př́stup: nový aktér - Černá louka } \\
\text { s.r.o. a jeho role intermediátora mezi } \\
\text { dalšími aktéry (kulturní instituce, univerzity, } \\
\text { neziskový sektor, občanská společnost) }\end{array}$ \\
\hline Logika vládnutí & $\begin{array}{l}\text { Exkluzivní: autoritativní rozhodování } \\
\text { Top-down sestavování politiky: účelová } \\
\text { dotace od magistrátu města Ostravy na } \\
\text { vytvoření prihlášky do projektu EHMK }\end{array}$ & $\begin{array}{l}\text { Inkluzivní: sífování s dalšími kulturními } \\
\text { organizacemi, vypsání urbanistické } \\
\text { soutěže } \\
\text { Top-down řízení projektu ze strany Černé } \\
\text { louky s.r.o. }\end{array}$ \\
\hline Klíčoví aktéři & $\begin{array}{l}\text { Politici, zástupci kulturních institucí, První } \\
\text { veřejnoprávní s.r.o. - Čestmír Kopecký }\end{array}$ & $\begin{array}{l}\text { Politici, Černá louka s.r.o., umělci, úředníci } \\
\text { z rưzných odború magistrátu, nezávislí } \\
\text { architekti, Společnost Petra Parléře, Adam } \\
\text { Gebrian }\end{array}$ \\
\hline Cíle & $\begin{array}{l}\text { Materiální a krátkodobé - výstavba } \\
\text { infrastruktury, vyłvoření klastru }\end{array}$ & $\begin{array}{l}\text { Účelové a strategické - interní a externí } \\
\text { image města }\end{array}$ \\
\hline Kontext & $\begin{array}{l}\text { Ekonomická krize, transformace, } \\
\text { restrukturalizace }\end{array}$ & $\begin{array}{l}\text { Ekonomická krize, transformace, } \\
\text { restrukturalizace }\end{array}$ \\
\hline Shrnutí & Manažerský režim & Pluralitní režim \\
\hline
\end{tabular}

Zdroj: Bernt a kol. (2010); Rumpel a Slach (2012a); modifikováno autory

\section{Shrnutí}

Cílem předloženého př́spěvku byla analýza a hodnocení plánovaného projektu kulturně tažené urbánní regenerace klastru Černá louka v kontextu governance. V první části textu byly nastíněny obecné rysy kulturou tažené regenerace se zvláštním důrazem na vlajkové projekty a průmyslová města. Opomenuta nebyla také nezbytná kontextualizace do prostoru střední a východní Evropy. Hlavní závěry tohoto textu lze shrnout do čtyř základních bodů.

V prvé řadě projekt klastru Černá louka či celé kandidatury byl, minimálně ve fázi iniciace projektu, hnán příležitostmi ve vnějším prostředí, ne výsledkem dlouhodobé koncepce 
rozvoje města. Kultura totiž nebyla součástí dlouhodobého plánovacího procesu rozvoje města, jinak vyjádřeno, celý projekt kandidatury byl spíše výrazem „podnikatelského“ města. Město Ostrava pouze využilo př́ležitosti ucházet se o titul EHMK a prostřednictvím projektového záměru regenerace bývalého brownfieldu Černé louky získat absentující kapitál pro ekonomický rozvoj města za účelem růstu. Je proto otázkou, zda by plánované pozitivní efekty byly skutečně dosaženy, nebo zda by projekt nadměrně zatí̌il městské finance, a to za situace, kdy město čelí dalším výzvám ve spojení s procesem „smrštováni““.

Za druhé projekt poukázal na, v teorii zmíněné, přejímání „domnělých“ příkladů dobré praxe či nesouměřitelných kontextů (Boston). Plánovaná výstavba některých budov (inkubátor pro kreativní odvětví) byla minimálně sporná. $\mathrm{V}$ př́ípadě plné realizace kulturního klastru tak hrozil vznik tzv. „kargo kultu“ (Peck 2005).

Za třetí jsme zaznamenali, že governance na území města Ostravy se změnila ve smyslu vytvoření zcela nové, pro účely kandidatury vytvořené intermediární agentury Černá louka s.r.o., která disponovala politickou podporou a jistou exkluzivitou a která přispěla $\mathrm{k}$ formaci nových externích a interních sítí. Poté, co titul EHMK 2015 obdržela Plzeň, město Ostrava přestalo podporovat aktivity společnosti Černá louka s.r.o. a rozhodlo o ukončení její činnosti ke konci roku 2010, přičemž zmizel aktér (iniciátor) regenerace Černé louky a město přišlo o napojení na evropské kulturní sítě.

Za čtvrté není př́liš pochyb, že projekt klastru $\mathrm{v}$ jeho plném rozsahu se přesunul od „touženého“ $\mathrm{k}$ „,utopistickému“. A to nejen z důvodu neúspěchu kandidatury, nýbrž také z důvodu obecné městské „finanční úspornosti“ (urban austerity) (Peck 2012), násobené v konkrétním př́ípadě Ostravy úbytkem obyvatelstva města. Bylo by však chybou úplně opustit ideu regenerace Černé louky. Vzhledem k vybudování Nové Karoliny a Dolní oblasti Vítkovice se totiž zhoršuje již tak špatný stav městského centra. Pro naplnění integrovaného rozvoje vnitřního města je nezbytné prostor Černé louky využít, např́íklad odloženou stavbou vědecké knihovny, která by mohla být prvním zárodkem postupné regenerace Černé louky, potažmo celého vnitřního města.

Vzhledem $\mathrm{k}$ tematickému zaměření tohoto čísla nemůže závěrečná poznámka opomenout aspekt paměti místa. Klastr Černá louka měl vzniknout na místě prvního zábavního parku v Ostravě, který je také jejím prvním brownfieldem, tedy místem s dlouhou (minimálně na poměry Ostravy) pamětí. Projekt Černé louky přidal na toto místo další vrstvu paměti a je otázkou s otevřenou odpovědí, zda myšlenky do něj vtělené zůstanou pouze v paměti obyvatel města jako světlé představy o „černém“ městě, či zda přispějí k vytvoření nové „světlé“ budoucnosti ,černého“ města. Odpověd” nemůže dát nikdo jiný než město a jeho obyvatelé samotní.

\section{Literatura}

BERNT, Matthias, Chris COUCH, Matthew COCKS, Dieter RINK a Annegret HAASE. How to Study Governance in the Context of Shrink Smart Project? Guidance for Case Study Teams in Researching Workpackage 5. Internal Documents of the Project Consortium, 2010.

BIANCHINI, Franco, Jon DAWSON a Richard EVANS. Flagship projects in urban regeneration. In HEALEY, Patsy et al. (ed.) Rebuilding the City: Property-led Urban Regeneration. London: E and FN Spon, 1992, s. 245-255. ISBN 9780419172802. 
BIANCHINI, Franco a Charles LANDRY. The Creative City. London: Demos, 1995. ISBN 1-898309-16-7. BLAXTER, Loraine, Christina HUGHES a Malcolm TIGHT. How to research. 2nd. ed. Buckingham: Open University Press, 2001. ISBN 978-0335209033.

COUCH, Chris a Matthew COCKS. The Governance of Urban Shrinkage in the Liverpool City-Region, United Kingdom. Liverpool: Liverpool John Moores University, 2011. Workpackage 5, D10 Research Report. Dostupné také z: http://www.ufz.de/export/data/400/39022_D10_Liverpool_final.pdf.

DE FRANTZ, Monika. Culture-led urban regeneration: the discursive politics of institutional change. In LEARY, Michael a John MCCARTHY (eds.) Routledge Companion to Urban Regeneration: Global Constraints, Local Opportunities. London: Routledge, 2013. ISBN 978-0-415-53904-3.

DIGAETANO, Alan a Elizabeth STROM. Comparative Urban Governance. An Integrated Approach. Urban Affairs Review, 2003, roč. 38, č. 3, s. 356-395. ISSN 1078-0874.

EBERT, Ralf a Fridrich GNAD. Vorschläge zur Qualifizierung des „Black Meadow Clusters“ und zur Entwicklung der Kultur- und Kreativwirtschaft im Rahmen der Bewerbung der Stadt Ostrava um den Titel Europäische Kulturhauptstadt 2015. StadtArt, 2010.

EVANS, Graeme. Measure for Measure: Evaluating the Evidence of Culture's Contribution to Regeneration. Urban Studies, 2005, roč. 42, č. 5/6, s. 959-983. ISSN 0042-0980.

FELDMAN, Merje. Urban waterfront regeneration and local governance in Tallinn. Europe-Asia Studies, 2000, roč. 52, č. 5, s. 829-850. ISSN 0966-8136.

FLORIDA, Richard. The Rise of the Creative Class and How It's Transforming Work, Leisure, Community \& Everyday Life. New York: Basic Books, 2002. ISBN 978-1469281421.

GARCÍA, Beatriz. Cultural policy and urban regeneration in Western European cities: Lessons from experience, prospects for the future. Local Economy, 2004, roč. 19, č. 4, s. 312-326. ISSN 0966-8136.

GRODACH, Carl a Daniel SILVER. The Politics of Urban Cultural Policy. New York: Routledge, 2013. ISBN 978-0415683784.

HALL, Tim a Phil HUBBART. The entrepreneurial city: new urban politics, new urban geographies. Progress in Human Geography, 1996, roč. 20, č. 2, s. 153-174. ISSN 0309-1325.

HARVEY, David. From Managerialism to Entrepreneurialism: The Transformation in Urban Governance in Late Capitalism. Geografiska Annaler. Series B, Human Geography, 1989, roč. 71, č. 1, s. 3-17. ISSN 1468-0467.

HAVRLANT, Miroslav. Geografie Severomoravského kraje. Ostrava: Pedagogická fakulta Ostravské univerzity, 1980.

HUBBARD, Phil. Urban design and city regeneration: social representations of entrepreneurial landscapes. Urban Studies, 1996, roč. 33, č. 8, s. 1141-1461. ISSN 0042-0980.

JANN, Werner a Kai WEGRICH. Phasenmodell und Politikprozesse. In SCHUBERT, Klaus a Nils BANDELOW (eds.). Lehrbuch der Politikfeldanalyse. München, Wien: Oldenbourg Verlag, 2003, s. 71-104. ISBN 978-3486272840.

JANN, Werner a Kai WEGRICH. Theories of the Policy Cycle. In FISCHER, Frank and Gerald MILLER (eds.). Handbook of Public Policy Analysis. Theory, Politics and Methods. Boca Raton: CRC Press, 2007, s. 43-62. ISBN 1574445618.

KEIVANI, Ramin, Ali PARSA a Stanley McGREAL. Globalization, institutional structures and real estate markets in Central European Cities. Urban Studies, 2001, roč. 38, č. 13, s. 2457-2476. ISSN 0042-0980.

KOOIMAN, Jan. Governing as governance. Thousand Oaks (CA): SAGE, 2003. ISBN 07-619-4036-7. KUNZMANN, Klaus. Kultur, Wirtschaft und Raumentwicklung. Informationen zur Raumentwicklung, 2002, roč. 4, č. 4/5, s. 185-197. ISSN 0303-2493.

LANG, Thilo. Insights in the British Debate about Urban Decline and Urban Regeneration [online]. 2005 [cit. 20. 11. 2013]. Dostupné z http://www.irs-net.de/download/wp_insights.pdf.

LASH, Scott a John URRY. Economies of Sign and Space. London: SAGE, 1994. ISBN 9780803984721. 
LITTLE, Stephen. LIVERPOOL '08 - brand and contestation. In MALÍKOVÁ, Ludmila a Martin SIRÁK (eds.). Regional and Urban Regeneration in European Peripheries: What Role for Culture? Bratislava: Institute for Public Policy, 2008, s. 44-50. ISBN 978-80-88721-21-5.

MILES, Malcolm. Cities and Cultures. Oxford: Routledge, 2007. ISBN 9780415354431.

MILES, Malcolm, Tim HALL a Iain BORDEN (eds.). City Cultures Reader. London: Routledge, 2000. ISBN 978-0415302456.

MOMMAAS, Hans. Cultural clusters and the post-industrial city: towards the remapping of urban cultural policy. Urban Studies, 2004, roč. 41, č. 3, s. 507-532. ISSN 0042-0980.

MULÍČEK, Ondřej. Prostorové vzorce postindustriálního Brna. In FERENČUHOVÁ, Slavomíra, Lucie GALČANOVÁ, Magdalena HLEDÍKOVÁ a Barbora VACKOVÁ (eds.). Město: proměnlivá nel samozrejmost. Brno: Masarykova univerzita, 2007, s. 153-175. ISBN 978-80-210-4866-9.

OSTRAVA 2015. Přihláška na titul Evropské hlavní město kultury 2015 [online]. OSTRAVA 2015, (C2010 [cit. 20. 11. 2013]. Dostupné z: http://www.ostrava2015.cz/web/structure/projektostrava2015-150.html/.

PECK, Jamie. Struggling with the Creative Class. International Journal of Urban and Regional Research, 2005, roč. 29, č. 4, s. 740-770. ISSN 0309-1317.

PECK, Jamie. Austerity urbanism. American cities under extreme economy. City: analysis of urban trends, culture, theory, policy, action, 2012, roč. 16, č. 6, s. 626-655. ISSN 1360-4813.

PLOGER, John. Millennium Urbanism - Discursive Planning. European Urban and Regional Studies, 2001, roč. 8, č. 1, s. 63-72. ISSN 0969-7764.

POLÁŠEK, Miloš a Bohuslav ŽÁRSKÝ. Jsem Černá louka. Ojedinělý přiběh jednoho místa. Ostrava: En Face, 2007. ISBN 978-80-903385-5-5.

RICHARDS, Greg. The European Cultural Capital Event: Strategic Weapon in the Cultural Arms Race? Journal of Cultural Policy, 2002, roč. 6, č. 2, s. 159-181. ISSN 1028-6632.

RICHARDS, Greg a Julie WILSON. The Impact of Cultural Events on City Image: Rotterdam, Cultural Capital of Europe 2001. Urban Studies, 2004, roč. 41, č. 10, s. 1931-1951. ISSN 0042-0980.

RINK, Dieter a Petr RUMPEL (eds.). Governance of Shrinkage. Lessons learnt from Analysis for Urban Planning and Policy. European Commission, 2012. Research Report, Workpackage 7. Dostupné také z: http://www.ufz.de/export/data/400/39029_WP7_D13_14_15_FINAL_2.pdf.

RUMPEL, Petr, Ondřej SLACH a Jaroslav KOUTSKÝ. Měkké faktory regionálního rozvoje. Ostrava: Ostravská univerzita, 2008. ISBN 978-80-7368-435-8.

RUMPEL, Petr, Ondřej SLACH, Jaroslav KOUTSKÝ a Pavel BEDNÁŘ. Re-imageing of industrial cities in the Czech Republic: chosen drivers of the change. Mönchengladbacher Schriften zur wirtschaftswissenschaftlichen Praxis, 2010, roč. 22, č. 1, s. 89-114. ISSN 1615-9160.

RUMPEL, Petr a Ondřej SLACH. Governance of shrinkage of the city of Ostrava. Praha: European Science and Art Publishing, 2012a. ISBN 978-80-87504-19-2.

RUMPEL, Petr a Ondřej SLACH. Je Ostrava smrštujícím se městem? Sociologický časopis, 2012b, roč. 48, č. 5, s. 859-878. ISSN 0038-0288.

SAGAN, Ivona a Maja GRABKOWSKA. Urban regeneration in Gdaňsk, Poland: Local regimes and tensions between top-down strategies and endogenous renewal. European Planning Studies, 2012, roč. 20, č. 7, s. 1135-1154. ISSN 0965-4313.

SCHMITT, Thomas. Cultural Governance as a conceptual framework. Göttingen: Max Planck Institute for the Study of Religious and Ethnic Diversity, 2011. MMG Working Paper 11-02. ISSN 2192-2357. Dostupný také z: http://www.mmg.mpg.de/fileadmin/user_upload/documents/wp/ WP 11-02_Schmitt_Cultural-Governance.pdf.

SHORT, John R., Lisa M. BENTON, W. B. LUCE a J. WALTON. Reconstructing the image of an industrial city. Annals of the Association of American Geographers, 1993, roč. 83, č. 2, s. 207-224. ISSN 0004-5608. 
SLACH, Ondřej, Tomáš BORUTA a Petr RUMPEL. Project-oriented planning in the framework of IBA Emscher Park. Regionální studia, 2009, č. 2, s. 38-44. ISSN 1803-1471.

SLACH, Ondřej a Tomáš BORUTA. What can cultural and creative industries do for urban development? Three different stories from the post-socialist industrial city of Ostrava. Quaestiones Geographicae, 2012, roč. 31, č. 4, s. 99-112. ISSN 2081-6383.

SPAANS, Marjolein. The Implementation of Urban Regeneration Projects in Europe: Global Ambitions, Local Matters. Journal of Urban Design, 2004, roč. 9, č. 3, s. 335-349. ISSN 1357-4809.

SWYNGEDOUW, Erik, Frank MOULAERT a Arantxa RODRIGUEZ. Neoliberal Urbanization in Europe: Large-Scale Urban development Projects and the New Urban Policy. Antipode, 2002, roč. 34, č. 3, s. 542-577. ISSN 0066-4812.

SÝKORA, Luděk. Global competition, sustainable development and civil society: three major challenges for contemporary urban governance and their reflection in local development practices in Prague. Acta Universitatis Carolinae Geographica, 2002, roč. 37, č. 2, s. 65-83. ISSN 0300-5402.

SÝKORA, Luděk a Stefan BOUZAROVSKI. Multiple Transformations. Conceptualising the Postcommunist Urban Transition. Urban Studies, 2012, roč. 49, č. 1, s. 43-60. ISSN 0042-0980.

TASAN-KOK Tuna a Guy BAETEN. Contradictions of Neoliberal Planning. New York: Springer, 2012. ISBN 978-90-481-8923-6.

UN-HABITAT. UN: Un-Habitat [online]. UN, C2009 [cit. 26. 11. 2013]. Dostupné z: http://www. unhabitat.org.

Rozhovory byly realizovány s př́mými aktéry plánované regenerace Černé louky, a to Karlem Burdou (ředitelem společnosti Ostravské výstavy a.s.), Andrejem Harmečkem (ředitelem multižánrového klubu Cooltour, který sídlí v areálu Černé louky), Michalem Hrotíkem (tehdejším vedoucím Odboru zdravotnictví a kultury magistrátu města Ostravy) a Lukášem Brusem (architektem, který se zúčastnil veřejné urbanistické soutěže na návrh revitalizace Černé louky).

\section{Autoři}

Blanka Marková je interní studentkou doktorského studia Politické a kulturní geografie na Katedře sociální geografie a regionálního rozvoje Ostravské univerzity v Ostravě, přičemž její pozornost poutají otázky kulturní governance, kulturního cestovního ruchu či regenerace brownfields prostřednictvím kultury.

Kontakt: blanka.markova@osu.cz

Ondřej Slach působí jako odborný asistent na Katedře sociální geografie a regionálního rozvoje Ostravské univerzity v Ostravě. V rámci své vědecké činnosti se specializuje na ekonomickou geografii s důrazem na průmysl, staré průmyslové regiony, kreativní odvětví a problematiku rozvoje vnitřních měst.

Kontakt: ondrej.slach@osu.cz 